\title{
Sciendo
}

10.2478/topling-2021-0003

\section{Modalized speech acts in a spoken learner corpus: The case of can and could}

\author{
Petra Huschová* \\ University of Pardubice, Czech Republic
}

\begin{abstract}
This paper examines the use of the modal auxiliaries can and could in speech acts produced by university students of English. Its aim is to explore syntactic patterns, semantic features and pragmatic functions of utterances containing can/could in Corpus of Czech Students' Spoken English. Taking account of pragmatic factors, including broader linguistic and extralinguistic context, the analysis attempts to identify the illocutionary forces conveyed by the modalized speech acts excerpted from the corpus dialogues. The findings indicate that the modal verbs are commonly employed as a modifying device in indirect speech acts, particularly in conventionalized directives. As for their frequency of occurrence, can proves to be a widely used modal auxiliary in spoken learner discourse, whereas the more remote could appears in the corpus much less frequently in that it is associated with a higher degree of diffidence.
\end{abstract}

\section{Key words}

speech acts, directives, can, could, spoken learner corpus, non-native speakers of English

\section{Introduction}

This paper presents and discusses findings of an investigation into the occurrence and use of modalized speech acts in a learner corpus of spoken English. It examines the speech acts containing can or its past tense form could, i.e. the modal verbs "notably more frequent than other modals" (Quirk et al., 1985, p. 136). Coates (1983) observes that can, along with will, is the most frequently occurring modal that seems "to be far more common in spoken than in written language" (p. 24), adding that it is one of the modal auxiliaries acquired first by children. Leech's study (2003, pp. 231-234) states that, in comparison with many other modal auxiliaries, can showed an increase in spoken discourse in the period from 1961 to 1992. In short, can is highly frequent in English, particularly in the language of conversation (cf. Biber et al., 1999; Biber and Conrad, 2009; Collins, 2009).

Regarding the meaning of can and could, both primarily convey possibility (Coates, 1983; Palmer, 1990; Leech, 2004; Collins, 2009; Huschová, 2014), however, their possibility reading may change in various speech acts. Siemund (2018, p. 139) argues that adding a modal to a clause results, on the basis of contextual determinants, in changing the illocutionary force. For example, the potential possibility or ability meaning of can/could is, according to Blum-Kulka (1987, p. 141), conventionalized in interrogative structures because they communicate indirect requests (e.g. Can/could you help us?). Levinson (1983, p. 268) considers such forms "idioms for 'I request you to VP"'.

Accordingly, the main objectives of the present paper are to interpret the modalized speech acts excerpted from Corpus of Czech Students' Spoken English on the basis of their contexts of occurrence and to categorize the readings of can/could from the perspective of speech acts. Since the two modal

\footnotetext{
*Address for correspondence: Petra Huschová, Department of English and American Studies, University of Pardubice, Studentská 84, 53009 Pardubice, Česká republika. Email: petra.huschova@upce.cz
} 
verbs are an indispensable element in native face-to-face interaction, they are expected to be commonly used in spoken discourse produced by university students of English (B2 level according to the CEFR). It should be noted that this paper does not aim to compare the occurrence of can/could in the analysed learner corpus to their occurrence in a reference native corpus. The major issue it addresses is related particularly to their interpretation in different communicative situations.

\section{Readings of can/could}

\subsection{Semantic perspective}

The modal verb can encodes ability, permission or possibility. Biber et al. (1999) state that in conversation ability and permission prevail but admit that it is often difficult to say "whether it [can] marks logical possibility, ability, or permission" (p. 492). Coates (1983, p. 86) perceives the meaning of can as a gradient of inherency and restriction, which implies that ability and permission can be interpreted as possibility due to inherent properties of subject or lack of restriction. Likewise, Quirk et al. (1985) consider ability to be "a special case of the 'possibility' meaning, viz one in which the possibility of an action is due to some skill or capability on the part of the subject referent" (p. 222). Dušková et al. (2006, p. 186) add that can conveys possibility if the subject and content are incompatible with the ability reading (cf. Leech, 2004, p. 75). In consequence, the core meaning of neutral possibility applies if "there is no clear indication either of restriction or of inherent properties of the subject" (Coates, 1983, p. 93).

The readings of can discussed above are exemplified in (1) and (2) from the analysed corpus:

(1) they don't have money for university life and it can be difficult for them [...]

(2) because everyone has the internet on this University so they can find, easily find out (er) if you just copied

The utterance in (1) conveys neutral possibility, since the context does not indicate any restriction or inherent properties of the subject. It communicates that the situation can be potentially difficult for students due to external conditions, particularly lack of money. By contrast, although (2) mentions an enabling condition for the possibility reading of can, i.e. access to the internet, the context also implies the freedom to act thanks to ability and may be paraphrased it is possible for them to find the information due to external conditions and their ability, meaning that the ability and possibility reading are merged here.

The preterite form could encodes the same meanings as can, i.e. possibility, ability, permission; however, when referring to present or future time, it expresses a greater degree of tentativeness (Quirk et al., 1985, p. 233; Dušková, et al., 2006, p. 189). Lewis (1986, p. 112) describes uses of could as more remote than those of can, explaining that the "remoteness" can be related to time (past vs. present/future), likelihood (degree of certainty) or social relationship (politeness). The difference between the two verbs is illustrated in the corpus examples (3) and (4):

(3) And I like Anna K. so we can go together if you like.

(4) but we could, for example, come together to the night club some day, if you want to.

Remote could in (4) is more tentative due to communicating the speaker's hesitation concerning the potential future activity. Both can and could may convey possibility here, but would be likely interpreted as suggestions when one considers broader context. Downing and Locke (2006) note: "can lends itself to various pragmatic interpretations by implication", e.g. willingness, command, request, or existential (p. 392). The pragmatic interpretations of can/could will be discussed in the following sections.

\subsection{Pragmatic perspective}

The previous section indicates that the central and most frequent meaning of can/could is that of possibility (cf. Huschová, 2014), which corresponds to Palmer's (1990, pp. 83-84) observation that many examples of neutral possibility can in declarative structures simply indicate that an event is possible. However, as has been shown in (3) and (4), possibility can/could in declarative structures may 
suggest a course of action to the addressee (Quirk et al., 1985, p. 222). The modal verbs can modify the force of utterances and thus help mark indirect speech acts, i.e. utterances in which "there is no direct relationship between a sentence type and an illocutionary force" (Huang, 2014, p. 137). Palmer (1990) labels this use 'implication', explaining that "can is often used not simply to say what one can do or what is possible, but actually to suggest, by implication, that what is possible will, or should, be implemented" (p. 86). Following Palmer (1990), Collins (2009) remarks that dynamic implication "requires an expansion of the semantic framework into pragmatics" (p. 96). In other words, dynamic implication of can/could is a pragmatic extension of their possibility reading, for instance, when performing requests, offers, suggestions, instructions, invitations or advice (cf. Papafragou, 1998).

Pragmatic extension or dynamic implication of neutral possibility is exemplified in (5) and (6). Although the utterance in (5) can be paraphrased it is possible for me to give you a link, it is likely to be interpreted as an offer. Huddleston and Pullum (2002, p. 862) note that the propositional content does not correspond with the speaker's intention here and the illocutionary force differs from what is normally conveyed by a declarative structure.

(5) And also I can give you a link to the website.

(6) Ok, that's a lot, (er) and can you tell me, (er) when, (er) and where they take place?

In (6), the illocutionary force is obviously directive; an indirect request is performed even though the literal reading is related to possibility or ability (Is it possible for you/are you able to tell me?). This example demonstrates that interrogative structures with can/could often communicate requests (please tell me). Brown and Levinson (1987, p. 70), Yule (1996, pp. 55-56) or Siemund (2018, p. 168) agree that in English such structures represent fully conventionalized indirect requests (see 4.1 for further discussion).

As has been illustrated in 2.1, the directive function can also be identified in declarative structures where possibility can suggests an action to the addressee:

\section{(7) Oh well, you can google it.}

In examples like (7), occurring in familiar settings, can expresses "tactful or democratic imperative" and the speaker "suggests that a certain plan of action is possible" (Leech, 2004, p. 74). Quirk et al. (1985, p. 222) label this use "a quasi-imperative manner", adding that these addressee-oriented speech acts suggest a course of action politely.

Regarding the preterite form could, when it replaces can, a higher degree of politeness is signalled due to its tentativeness:

(8) I, (er) would like, (er) to study abroad for a semester in the second year (er) could you help me with it, please?

Obviously, (8) represents a hesitant and tentative request, which implies that the selection of more remote could usually involves considerations of politeness. Huddleston and Pullum (2002, p. 200) acknowledge that "the preterite introduces a rather vague element of tentativeness, diffidence, extra politeness, or the like".

The previous paragraphs imply that the interpretations of can/could are dependent on the structure of the proposition as well as on contextual assumptions (Papafragou, 2000, p. 54). When used with second-person subjects in interrogative structures, can/could convey indirect requests, meaning that the addressee is responsible for carrying out the action beneficial to the speaker, as in (6) or (8). In contrast, when the modal verbs co-occur with first-person subjects in declarative structures, they may communicate offers; consider (5), where it is the speaker that is responsible for bringing about the course of action beneficial to the addressee. Matthews (2003) concludes that the interpretation of particular instances is "determined by construction, context and convention" (p. 66). These factors are applied when interpreting the modalized speech acts in the corpus of spoken learner discourse.

In conclusion, following Searle's typology $(1969,1979)$, the main categories of speech acts conveyed by utterances including can/could, i.e. directives, commissives and representatives, are briefly characterized. Firstly, directives are addressee-oriented speech acts, defined by Searle (1979, p. 13) as 
"attempts by the speaker to get the hearer to do something". Martínez-Flor (2005, p. 168) remarks that they require interaction between the participants in order to get the act performed and thus contribute to the natural flow of conversation. The major illocutionary forces of directives with the modal verbs can/could include requests, suggestions and questions. When a request is produced, the hearer is supposed to carry out an action that is beneficial to the speaker. Questions are similar to requests in that their purpose is to request an answer (Searle, 1969, p. 69), i.e. to seek particular information that the speaker does not know. When suggesting some course of action, contrary to requests, the speaker believes that the desired action will benefit the addressee (Searle, 1969, pp. 66-67). Secondly, commissives are "illocutionary acts whose point is to commit the speaker to some future course of action" (Searle, 1979, p.14). In order to distinguish commissives from directives, one has to consider their propositional content; the content of commissives concerns the future action carried out by the speaker (Huang, 2014, p. 133), whereas that of directives concerns the addressee's future behaviour (cf. Recanati, 1987). Regarding the illocutionary force, commissives containing can/could typically convey offers. Finally, representatives are the acts that "commit the speaker to the truth of the expressed proposition" (Huang, 2014, p. 133), meaning that they can be characterized as acts of stating which can be assessed true or false.

\section{Corpus data description}

The source of data for my analysis is the Czech Students' Spoken English (CSSE) corpus. This corpus, built at the Department of English and American Studies of the University of Pardubice, comprises informal spoken English (153,295 words) recorded in monologues and dialogues performed by 228 undergraduate learners of English. The subjects were first-year students (aged 19 to 22) enrolled in a TEFL programme at a Czech university (in Pardubice, České Budějovice or Olomouc) and they were all native speakers of Czech. Their average English language proficiency was B2 level of the Common European Framework of Reference for Languages, the officially declared level of secondary school graduates in the Czech Republic. The majority of the students were females (161 out of 228), which indicates that traditionally more women than men are enrolled in TEFL study programmes. Although the sample included both male and female, gender was not the focus of my interest. In sum, it can be argued that the sample represents a rather homogenous group of young adult Czech learners of English (Ježková, 2015).

In order to collect modalized speech acts containing can and could, 228 student-student dialogues have been analysed. The dialogues are information transfer tasks (3-4 minutes long); one student was given specific information on a particular topic and the other student was supposed to elicit the information, then they swapped their roles with a new topic. The tasks represent open role-plays requiring students to engage in the interaction actively, which enabled me to examine modalized speech acts in their natural discourse context. The setting of the dialogues is informal, the participants are friends, and the topics covered are related to their studies, for example, applying for an Erasmus study visit, studying English abroad, sports events at the university, summer camps in the USA, part-time jobs, or looking for accommodation.

\section{Discussion of findings}

In the 228 role-plays analysed, 1,123 instances of modalized speech acts containing can/could have been identified. The overall findings presented in Figure 1 show that can is a very common and widely used modal auxiliary in spoken learner discourse; 893 instances have been detected, with can appearing in almost each dialogue (93\% of the dialogues). On the other hand, could is much less frequent; only 230 instances have been identified in less than half of the role-plays ( $46 \%$ of the dialogues). As proposed in section 2, could is a more tentative and remote form of can, the use of which is determined by social relationship. Considering the fact that the setting of the role-plays is familiar, the participants are classmates and their relationship is symmetrical, it is not surprising that they favour can to communicate their intentions. 


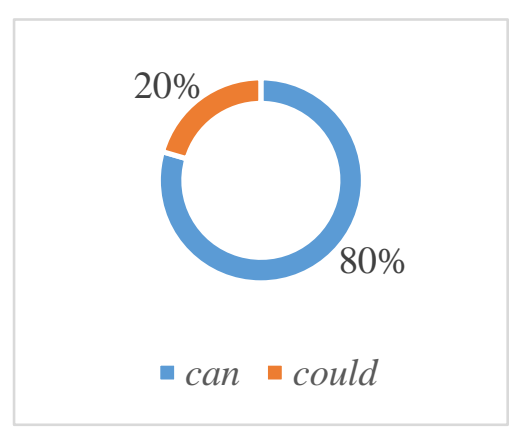

Figure 1. Occurrence of can and could in the corpus dialogues

Despite the fact that could is more tentative and polite than can, both convey identical illocutionary forces in the CSSE corpus, however, with a different frequency (see $4.1-4.3$ ). Table 1 indicates that slightly more than half of the modalized speech acts recorded are interpreted as directives, whose function is to make the addressee act. This function corresponds to the purpose of the dialogues - to elicit information on a particular topic. Similarly, the use of the other frequent category, modalized representative speech acts, is related to the goal of the dialogues - to provide information elicited by directives. On the other hand, as Table 1 shows, commissives with can/could are rather scarce because there is not much space for offers or promises in the role-plays analysed.

To sum up, modalized directives and representatives prevail in the CSSE corpus due to the fact that the dialogues focus primarily on demanding and giving information, two basic speech roles in any verbal exchange (cf. Thompson, 2014, p. 47). Each category of the speech acts recorded will be discussed and exemplified in the following subsections.

\begin{tabular}{lcc} 
Table 1. Modalized speech acts in the CSSE corpus & \\
\hline $\begin{array}{l}\text { Modalized speech act (MSA) } \\
\text { Directive }\end{array}$ & $\begin{array}{c}\text { No of MSAs } \\
\text { (suggesting, asking, requesting) }\end{array}$ & 593 \\
$\begin{array}{l}\text { Representative } \\
\text { (stating/explaining) }\end{array}$ & 478 & 52.8 \\
$\begin{array}{l}\text { Commissive } \\
\text { (offering) }\end{array}$ & 52 & 4.6 \\
Total & $\mathbf{1 , 1 2 3}$ & $\mathbf{1 0 0}$ \\
\hline
\end{tabular}

\subsection{Directives}

The prevalent category in the corpus role-plays proved to be directive speech acts (see Table 1), which is also the most variable category, including the illocutionary forces of requesting, suggesting and asking (see Table 2).

Table 2. Interpretation of directives containing can/could

\begin{tabular}{llcc}
\hline Directive speech act & structure & No of instances & \% \\
Request & interrogative & 230 & 38.8 \\
Suggestion & declarative & 192 & 32.4 \\
Question & interrogative & 171 & 28.8 \\
Total & & $\mathbf{5 9 3}$ & $\mathbf{1 0 0}$ \\
\hline
\end{tabular}

In the dialogues analysed, the most frequent role of directives is to elicit a verbal response from the other participant, as in (9), interpreted I want you to tell me. Regarding the usage of can and could in directives, Figure 2 shows that could is most frequently employed in polite and tentative requests (cf. Huddleston and Pullum, 2002, p. 200). 


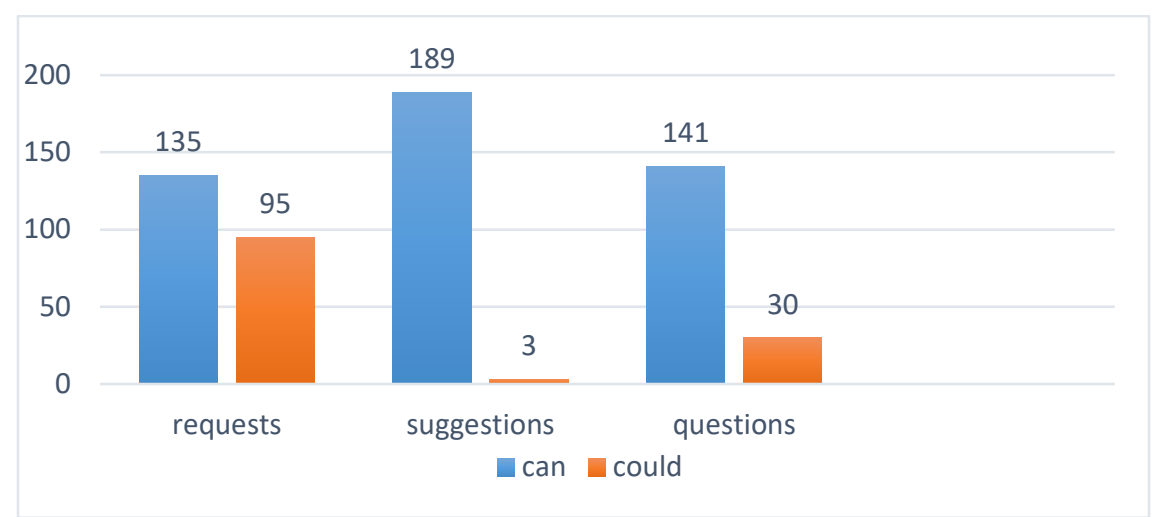

Figure 2. Distribution of can and could in directive speech acts

\subsubsection{Requests}

When producing requests in the CSSE corpus, the speakers desire to get the hearers to provide particular information, as in (9). Although these utterances literally ask about ability or external possibility (are you/would you be able to... or is it/would it be possible for you to tell me/give me information), the question force is backgrounded and, as has been explained in 2.2, the speakers communicate requests by implication (cf. Palmer, 1990).

(9) a. So, and can you give me, (er) some information about price?

b. So can you tell me something more about (er) [...] (er) [...] that semester course?

c. Could you tell me what, what will I be doing?

Siemund (2018, pp. 165-168) considers such polar interrogative structures in which the verb describes an activity beneficial to the speaker a standard way of indirectly conveying a request in English. Huddleston and Pullum (2002, pp. 200, 205) add that questions about ability or deontic possibility employed as indirect requests prototypically occur with a second-person subject. The findings correspond with these accounts; conventionalized interrogative structures with the subject you prevail in the CSSE corpus, comprising $60 \%$ of all the requests. The most frequent structure is Can/could you tell me... (107 instances), where the task of telling delegated to the addressee is beneficial to the speaker, who needs to get a particular piece of information, for example, in (9), the information regarding a price, a semester course or responsibilities related to a particular job.

Brown and Levinson (1987, p. 132), characterizing requests as inherently face-threatening speech acts, argue that indirect requests seem to be socially and culturally more appropriate in that they avoid or mitigate the potential face threat. Obviously, Brown and Levinson see a correlation between indirectness and politeness, which is in alignment with Leech's claim that indirectness can increase the degree of politeness because it implies optionality for the hearer (Leech, 1983, p. 108). However, Ogiermann (2009, p. 191) notes that equating indirectness with politeness reflects Anglo-Saxon cultural values (cf. Leech and Larina, 2014). Studies investigating directive speech acts agree that this model of politeness has a Western bias and point out culture-specific preferences in the degree of (in)directness of requests. Wierzbicka (1985), addressing the issue of different cultural norms and assumptions, maintains that it is English that prefers interrogative requests; in Slavic languages they are avoided in daily communication because they may be perceived as "elaborately polite" (pp. 151-153). Likewise, Leech and Larina (2004, pp. 15, 26) observe that indirect requests are used by Russian speakers mostly in formal contexts and add that they might be interpreted as questions rather than requests.

A closer analysis of requests for information in the CSSE corpus shows that the dominant means is a direct question (1,072 out of 1,367 utterances classified as requests for information), whereas request moves representing indirect speech acts comprise 295 instances. This result is in line with Reiter's conclusion "the more familiar the participants the more direct the strategy" (Reiter, 2000, p. 103). Chejnová's study, exploring the directness level of Czech students' email requests addressed to faculty, reports that, even though Czech students prefer direct strategies, they commonly employ conventionally indirect strategies, particularly requests including conditional mode, modal verbs and past tense 
(Chejnová, 2014, p. 187). In the CSSE corpus, modalized requests with both can and could also represent a significant category of directive speech acts (see Figure 2).

Regarding differences between can and could, Coates (1983, p. 121) states that in requests "it is conventional to substitute could for can as a mark of politeness". Similarly, Huddleston and Pullum (2002, p. 200) characterize the preterite form as slightly more diffident and polite. As a result, in English, requests with can are employed when the relationship between interlocutors is close, e.g. when talking to friends, whereas more polite could is favoured when there is social distance, e.g. in formal settings or when talking to strangers (cf. Lewis, 1986). Ogiermann (2009) observes that "the relatively low frequency of conditional constructions is likely to be related to the informal character of the situation" (p. 199). In the requests analysed, can is preferred due to their low degree of imposition and familiar setting. Nevertheless, the modal auxiliary could functioning exactly like can - compare (9b) and (9c) is quite frequent (see Figure 2), and in many requests the two verbs are employed interchangeably. Yet, could seems to be associated with greater politeness (cf. Palmer, 1990) because it co-occurs more often with the politeness marker please (please appears in 16 requests with could, and only in 4 with can).

Apart from the interrogative structures with the second-person subject, $40 \%$ of the requests in the corpus role-plays include the first-person subject $I$ :

(10) a. Can I ask you, (er) which level is needed to pass the exams of English? b. So, can I start?

Even though the speakers in (10) literally ask for permission to do an activity themselves (is it possible for me to ask you/start...), they in fact inform the addressees about the activity they are going to perform, and thus their utterances can be paraphrased I'm going to ask you/start. Palmer (1990, p. 78) explains that "permission is sought as a matter of courtesy" and a positive answer from the addressee is expected. Accordingly, when the commonly occurring utterance Can I ask you (33 instances) is produced, the addressee is not expected to give permission, but to provide a relevant answer.

In summary, the findings indicate that interrogative structures containing can/could are often employed as conventional requests by Czech learners when particular information is sought. Although conventional interrogative requests typically occur in formal settings or face-threatening situations, Hassall (1999, p. 600) or Reiter (2000, p.104) note that they are the most common type of request across cultures, which could explain their occurrence in the dialogues analysed.

\subsubsection{Suggestions}

In the corpus dialogues, the speakers often suggest an action that should be best for their addressees:

(11) a. You can visit Afi palace. There is one cinema.

b. Yeah, you can go to the Maxim, it's music bar.

c. and if you want to relax you can try a table tennis lesson.

The suggested actions in (11) are literally taken as possible for the addressees (it is possible for you to visit/go/try...), implying that the reading of can is again related to its central possibility meaning. Papafragou (2000, p. 58) interprets can in such utterances as "introducing possibilities where there were previously none".

Since a proposed action is usually supposed to be performed by the addressee, in the majority of cases $(90 \%)$, possibility can in declarative structure co-occurs with a second-person subject, see (11). Although examples like (11) seem to be neutral with regard to politeness, Leech $(2004$, p. 74$)$ would label them tactful imperatives, arguing that they are less directive than commands and allow the addressee to give a negative response. Such modalized suggestions commonly occur in familiar settings and, according to a taxonomy proposed by Martínez-Flor (2005, p. 175), represent conventionalized indirect speech acts. The remaining suggestions recorded (10\%) employ inclusive we, which indicates that both the speaker and the addressee are concerned with the result, and the action proposed is thus perceived as beneficial to both of them: 
(12) a. $O k$, (er) so we can go together and...

b. Yeah, we can try to find some.

c. So, we could go together.

As regards the use of can and could in suggestions, the findings (see Figure 2) reveal that could is very rare in the CSSE corpus. For example, we could go together (12c) sounds hesitant in comparison with we can go together (12a) and may imply a possible negative response. Coates (1983, pp. 120-121) remarks that hypothetical could makes the suggestion more tactful and Biber et al. (1999, p. 485) add that it conveys "overtones of tentativeness and politeness". Consequently, could might be preferred in contexts where there is a higher degree of imposition or a greater distance between interlocutors.

\subsubsection{Questions}

Questions are normally interrogative structures whose purpose is to find particular information. All the modalized questions identified in the CSSE corpus have a primary information-seeking function, specifically they ask about external possibilities enabling the action:

(13) a. Can I get there by bus or by train?

b. How many credits can I get?

c. How could I prepare for it?

d. And do you know which countries could I visit?

The utterances in (13) are prototypical informationally incomplete questions. The majority of questions (86\%) co-occur with the subject $I$, implying that the speaker seeks an answer that he/she does not know and by employing can/could inquires about various possibilities, e.g. the possibilities of transport (13a) or the ways of preparing for an exam (13c).

In the CSSE corpus, both questions and requests have the same function, they are addressee-oriented acts expecting the addressee to supply a verbal response. However, whereas questions represent direct speech acts, requests are indirect speech acts (cf. Huddleston and Pullum, 2002, pp. 866-867). Another difference, mentioned by Palmer (1990), is the occurrence of please in requests. The marker please is not used in questions because it would turn them into requests (Biber et al., 1999, p. 207). Leech (2014, p. 162) argues that please may be considered an illocutionary marker rather than a politeness marker. Similarly, Siemund (2018, p. 32) claims that, when using please, one performs the act of a request, expressing "polite request force".

\subsection{Representatives}

The data in Table 1 show that nearly half of the modalized speech acts gathered have been classified as representatives, specifically the acts of stating or explaining because the students are supposed to inform each other about possibilities available:

\section{(14) a. You can get there ten per cent discount \\ b. You can use it anywhere because it is internationally accepted \\ c. it can be prolonged up to twelve months, but...}

The instances in (14) demonstrate that the representatives recorded are declarative structures, typically with the second-person subject you (62\% of the representatives), implying that the participants address each other directly. Nevertheless, the subjects in (14a) and (14b) could be labelled "general", i.e. any student can get the discount or can use the card anywhere, and the utterances interpreted as statements of neutral/theoretical possibilities. This is in alignment with Palmer's (1990, p. 84) observation that, when can occurs with impersonal you or the passive (see 14c), its sense of neutral possibility is even clearer. Recanati (1983, p. 169) proposes that declarative sentences are, unlike other structures, force-neutral or unmarked, which means that their illocutionary potential is neutral and determining their exact force is thus a matter of contextual interpretation. Following this proposal, the representatives in the CSSE corpus are interpreted on the basis of context as the acts expressing the speakers' beliefs and stating possibilities typically bringing some benefits to the addressee, as in (14). 
Table 3. Occurrence of can and could in representatives

\begin{tabular}{lcc}
\hline & No of instances & \% \\
can & 379 & 79 \\
could & 99 & 21 \\
Total & $\mathbf{4 7 8}$ & 100 \\
\hline
\end{tabular}

Unlike prevalent neutral possibility can (see Table 3), could in representatives encodes primarily hypothetical possibility ( 89 cases out of 99 ), i.e. a more tentative and distant reading from real possibility (cf. Coates, 1983). By employing could in (15a) the speaker informs the addressee about what would be theoretically possible (cf. Leech, 2004). In the remaining cases (10 instances out of 99), could conveys personal evaluation (Biber et al., 1999, p. 493), i.e. "the speaker's lack of confidence in the proposition expressed" (Coates, 1983, p. 165). Personal evaluation is exemplified in (15b), where the speaker is not certain whether the action will be interesting or not.

(15) a. You could earn twelve thousand crowns.

b. I think this could be interesting.

\subsection{Commissives}

Acts committing the speaker to some future course of action are infrequent in the CSSE corpus, comprising only $4.6 \%$ of all the modalized speech acts (see Table 1). The reason is, as has been suggested, the goal of the role-plays - to elicit and provide required information. Nevertheless, 52 commissives have been identified. All of them have declarative structure and typically include the subject $I$, exemplified in (16):

\section{(16) a. And also I can give you a link to the website \\ b. $O K$, I can tell you phone number \\ c. Yes, I can offer you Semester course or Preparation course for CAE exam}

These utterances are not just statements of possibility, but obviously offers, which can be paraphrased as I intend to give you/tell you/offer you, implying that the speaker intends to do something for the addressee. Offers with could are scarce (3 instances only) and, like other speech acts including could, seem to create a greater distance than offers with can.

\section{Conclusion}

The findings of the present paper confirm that in spoken learner discourse, similarly as in native spoken English, can is commonly employed. Since tentative could is selected in contexts implying social remoteness and a higher degree of politeness, it is not frequent in the CSSE corpus dialogues owing to their familiar setting, close relation of participants and low degree of imposition. As for interpretations of can and could, the findings indicate that their basic modal meanings (possibility, ability or permission) change in different sentence structures and contexts. The main factors that have proved to be crucial for their interpretation are clause type, grammatical subject, and discourse context (cf. Matthews, 2003). Following Papafragou (1998, 2000), the contextual assumptions that have been taken into account include propositional content of utterances, benefit of an action to the speaker/addressee and responsibility for bringing about an action. To sum up, due to so called "dynamic implication" (Palmer, 1990), the central possibility sense of can/could is pragmatically extended, meaning that the modalized speech acts in the CSSE corpus are not interpreted only as mere assertions of possibility, but often as requests, suggestions or offers (cf. Collins, 2009).

Since the primary goal of the dialogues analysed is to exchange information, the prevailing categories of modalized speech acts in the CSSE corpus are directives (typically eliciting verbal information) and representatives (providing verbal information). In directive speech acts, the modals indirectly communicate that the speaker suggests a course of action to the hearer or wants the hearer to provide enquired information. The most distinctive directive is a conventionalized request with a second-person subject, particularly the interrogative structure Can/could you tell me.... Brown and Levinson (1987) state that such structures are "conventionalized to the extent that there can be no doubt about what is 
meant" (p. 133). This has been confirmed: conventionalized requests are not misinterpreted by Czech university learners. Additionally, they occur regularly in the CSSE corpus, which corresponds to Hassall's observation that they can be perceived as unmarked formulaic requests employed in almost every situation (Hassall, 1999, p. 594).

To conclude, the speech acts analysed will be briefly commented on with regard to students' performance. The analysis suggests that B2 learners of English communicate successfully; they are able to produce and interpret modalized speech acts containing can/could appropriately. Nevertheless, quite a large number of indirect speech acts are not well formed. In a quarter of complex indirect requests, inversion in embedded questions is erroneously used (e.g. Can you tell me how can I prepare...?). Apart from that, a limited variety of speech act forms has been identified; the students tend to rely on and favour uncomplicated familiar structures. Relying on the familiar is a phenomenon referred to as the use of "lexical teddy bears" by Hasselgren (1994), whose study concludes that even advanced learners (Norwegian university students) overuse familiar words and phrases because they feel safe with them (p. 251). Czech university learners of English seem to depend on familiar structures which they are most exposed to, i.e. conventionalized requests used in textbooks or by teachers (cf. Martínez-Flor, 2003; Chejnová, 2014).

Finally, limitations of the present study should be mentioned. Firstly, it focuses on the use of can/could only in Czech learners' spoken English; it would be helpful to compare Czech learners' performance against native speakers' use of the two modal verbs. Secondly, the paper examines can/could primarily from the perspective of situational variability; it would be useful to examine individual and cross-cultural variables thoroughly, for example, to explore whether there are any significant differences in the use of modalized speech acts regarding gender or to trace effects of pragmatic transfer on their production. Also, further research could take other modal verbs into consideration; it might be interesting to investigate modalized speech acts containing will and would.

\section{References}

Biber, D., Johansson, S., Leech, G., Conrad, S. and Finegan, E., 1999. Longman grammar of spoken and written English. London: Longman.

Biber, D. and Conrad, S., 2009. Register, genre, and style. Cambridge: Cambridge University Press.

Blum-Kulka, S., 1987. Indirectness and politeness in requests: Same or different? Journal of Pragmatics, vol. 11, pp. 131-146.

Brown, P. and Levinson, S. C., 1987. Politeness: Some universals in language usage. Cambridge: Cambridge University Press.

Chejnová, P., 2014. Expressing politeness in the institutional e-mail communications of university students in the Czech Republic. Journal of Pragmatics, vol. 60, pp. 175-192.

Coates, J., 1983. The semantics of the modal auxiliaries. London: Croom Helm.

Collins, P., 2009. Modals and quasi-modals in English. Amsterdam: Rodopi.

Downing, A. and Locke, P., 2006. English grammar: A university course. London/New York: Routledge.

Dušková, L., Strnadová, Z., Knittlová, D., Peprník, J. and Tárnyiková, J., 2006. Mluvnice současné angličtiny na pozadí češtiny. Praha: Academia.

Hassall, T., 1999. Request strategies in Indonesian. Pragmatics, vol. 9, no. 4, pp. 585-606.

Hasselgren, A., 1994. Lexical teddy bears and advanced learners: A study into the ways Norwegian students cope with English vocabulary. International Journal of Applied Linguistics, vol. 4, no. 2, pp. 237-258.

Huang, Y., 2014. Pragmatics. Oxford: Oxford University Press.

Huddleston, R. and Pullum, G., 2002. The Cambridge grammar of the English language. Cambridge: Cambridge University Press.

Huschová, P., 2014. Possibility readings of CAN and MAY and their potential interchangeability. Brno Studies in English, vol. 40, no. 1, pp. 89-104.

Ježková, Š., ed., 2015. Corpus of Czech students' spoken English. Pardubice: Univerzita Pardubice.

Leech, G., 1983. Principles of pragmatics. London: Longman.

Leech, G., 2003. Modality on the move: The English modal auxiliaries 1961-1992. In: R. Facchinetti, M. Krug and F. Palmer, eds. Modality in contemporary English. Berlin: Mouton de Gruyter, pp. 223-240. 
Leech, G., 2004. Meaning and the English verb. London: Longman.

Leech, G., 2014. The pragmatics of politeness. Oxford: Oxford University Press.

Leech, G. and Larina, T., 2014. Politeness: West and East. Russian Journal of Linguistics, no. 4, pp. 934.

Levinson, S. C., 1983. Pragmatics. Cambridge: Cambridge University Press.

Lewis, M., 1986. The English verb: An exploration of structure and meaning. Hove: Language Teaching Publications.

Martínez-Flor, A., 2003. An analysis of request production by university and secondary school EFL students. ES, vol. 25, pp. 167-182.

Martínez-Flor, A., 2005. A theoretical review of the speech act of suggesting: Towards a taxonomy for its use in FLT. Revista Alicantina de Estudios Ingleses, vol. 18, pp. 167-187.

Matthews, R., 2003. Modal auxiliary constructions, TAM and interrogatives. In: R. Facchinetti, M. Krug and F. Palmer, eds. Modality in contemporary English. Berlin: Mouton de Gruyter, pp.47-70.

Ogiermann, E., 2009. Politeness and in-directness across cultures: A comparison of English, German, Polish and Russian requests. Journal of Politeness Research, vol. 5, no. 2, pp. 189-219.

Palmer, F., 1990. Modality and the English modals. London: Longman.

Papafragou, A., 1998. Modality and the semantics-pragmatics interface. discovery.ucl.ac.uk [Accessed 10 April 2020]. Available at: https://discovery.ucl.ac.uk/id/eprint/1317914/1/299914.pdf

Papafragou, A., 2000. Modality: Issues in the semantics-pragmatics interface. Oxford: Elsevier.

Quirk, R., Greenbaum, S., Leech, G. and Svartvik, J., 1985. A comprehensive grammar of the English language. London/New York: Longman.

Recanati, F., 1987. Meaning and force. Cambridge: Cambridge University Press.

Reiter, R. M., 2000. Linguistic politeness in Britain and Uruguay: A contrastive study of requests and apologies. Amsterdam: John Benjamins Publishing Company.

Searle, J. R., 1969. Speech acts: An essay in the philosophy of language. Cambridge: Cambridge University Press.

Searle, J. R., 1979. Expression and meaning: Studies in the theory of speech acts. Cambridge: Cambridge University Press.

Siemund, P., 2018. Speech acts and clause types: English in a cross-linguistic context. Oxford: Oxford University Press.

Thompson, G., 2014. Introducing functional grammar. London/New York: Routledge.

Wierzbicka, A., 1985. Different languages, different cultures, different speech acts: English vs. Polish. Journal of Pragmatics, vol. 9, pp. 145-178.

Yule, G., 1996. Pragmatics. Oxford: Oxford University Press. 